\title{
Teaching Facilitation of Family Participation in Educational Institutions
}

\author{
María Ángeles Gomariz ${ }^{1 *}$, Joaquín Parra ${ }^{1}$, Maria Paz García-Sanz ${ }^{1}$ and \\ María Ángeles Hernández-Prados² \\ ${ }^{1}$ Department Research Methods and Diagnostic in Education, Faculty of Education, University of Murcia, Murcia, Spain, \\ ${ }^{2}$ Department Theory and History of Education, Faculty of Education, University of Murcia, Murcia, Spain
}

OPEN ACCESS

Edited by:

James Ko,

The Education University

of Hong Kong SAR, China

Reviewed by:

José Gutiérrez-Pérez,

University of Granada, Spain

Kayi Ntinda

University of Eswatini, Eswatin

*Correspondence:

María Ángeles Gomariz magovi@um.es

Specialty section

This article was submitted to

Educational Psychology,

a section of the journal

Frontiers in Psychology

Received: 28 July 2021 Accepted: 10 December 2021 Published: 18 February 2022

Citation:

Gomariz MÁ, Parra J,

García-Sanz MP and

Hernández-Prados MÁ (2022)

Teaching Facilitation of Family

Participation in Educational

Institutions.

Front. Psychol. 12:748710. doi: 10.3389/fpsyg.2021.748710
The participation of families in schools where their children study is a recurring research topic. This field tends to address the perception of parents or teaching staff. This work is novel in that it considers what teachers, and not families, do to facilitate this participation. The purpose of this work has been to contrast a theoretical model with a multidimensional questionnaire designed to obtain information on the assistance provided by teachers to improve parental involvement in schools. It will allow us to lay the foundations for the content necessary for the initial and permanent training of teachers. Then, an initial questionnaire was created and, after being subjected to expert judgment, it was applied to 225 Spanish teachers, using a quantitative and a non-experimental methodology. After calculating the exploratory and confirmatory factor analysis and applying the structural equation model, a questionnaire (QFIS-TP) was obtained that had satisfactory construct validity and reliability.

Keywords: parent participation, teacher, questionnaire, validity, reliability

\section{INTRODUCTION}

The socioeconomic development of a country is closely tied to its education and ability to generate scientific-technological knowledge and innovations (Spanish Strategy of Science and Technology and of Innovation [EECTI], 2012). Improved educational quality depends not only on economic issues (Organisation for Economic Co-operation and Development [OECD], 2012, 2014), but also on the modernization of systems, through the development of associations and unions for innovation, to capitalize on existing resources (Europe Strategy 2020, 2015). It involves structural and functional changes that affect the school community, requesting the promotion of communication and participatory channels, especially between families and teachers.

Most countries in the European Union have taken on the challenge of promoting school democratization, reassessing the channels of family participation (European Commission, 2005) as a useful measure in response to scholastic failure and student dropout (Organisation for Economic Co-operation and Development [OECD], 2011), and opting for assessment processes that collect student and parent opinions on their educational implication (Maxwell and Staring, 2018). Ultimately, it has been recognized that parents are critical and demanding consumers of 
education who can contribute to its improvement through collaborative efforts, or to its decline through their passivity or destructive criticism (European Commission, 2000). In this dichotomy, the prevailing position depends on how family participation is understood, as well as the dynamics promoted by the teaching staff. So, the decision to participate depends on the feeling that one is welcomed by the school, children, and teachers, who utilize various means to express to parents that their participation is necessary and useful (Walker et al., 2005). But, in what content should teachers be trained to promote the participation of families in school?

In addition to the knowledge of degrees of family participation, the complexity of the question requires the creation of a theoretically solid instrument that allows measuring how teachers promote this participation. Although necessary, few studies have analyzed teachers as mediators or promoters of this participation (Erdener, 2016; Gomariz et al., 2017; Yulianti et al., 2019). This is the focal point of this work.

\section{Teachers as Promoters of Family Participation}

The main research question guiding the bibliographic review was focused on the role teachers play in family participation in the educational institutions. The lack of scientific research on this topic prevents the identification of the teacher's role in facilitating participation, limiting the search to relevant theoretical models, reviews, and meta-analyses from the past two decades. So, various theoretical models of family participation have been found. The model of Epstein (2011), which distinguishes between six modalities of family participation (parenting, communicating, volunteering, learning at home, decision making and collaborating with community); that of Vogels (2002), which considers four family profiles related to scholastic education (consumers, clients, participants and partners); the renewed model of Hoover-Dempsey and Sandler (Walker et al., 2005), focusing on the aspects that explain why parents get involved and how their participation improves the scholastic performance of their children (involvement decision, forms, influence, mediating variables and student outcomes); Hornby (2011), which includes eight types of family participation (communication, liaison, education, support, information, collaboration, resource, and policy) and that of Garbacz et al. (2019), which considers five participation dimensions (communication, expectations, educational support, community activities, and scholastic assistance). All of these provide a theoretical foundation to form the core of the Integral Model of Family Involvement in School-Teacher Promoter (IMFIS-TP), which we propose and detail below and which includes 7 dimensions. It is a new model that focuses on the teacher figure as the driving force behind specific actions that favor family participation in schools, and not only attributions or good intentions, since expressing the desire and need for increased participation does not contribute to making this participation a reality.

\section{Teacher-Family Communication}

The teacher's responsibility in the family communication process has been widely recognized, understanding that parent-teacher tutorials tend to be initiated upon request of the teachers, and less frequently, upon request of the families (Epstein, 2011; Tran, 2014). These communicative meetings offer unique opportunities for the "teacher-promoter" to foster the child's educational support from the home (Dettmers et al., 2019) and the families' sense of belonging to the center (Tran, 2014).

Parents need to understand diverse aspects of their children's' schooling and must feel that they are free to communicate via diverse channels and at any time. Therefore, teachers should offer families a wide range of communication channels (Hornby, 2011). The use of agendas, attitude toward participation, the language used, flexibilization of meeting schedules, and the use of the social networks all help to increase family participation, assuming the appropriate use of the same (Erdener, 2016).

\section{School Activities}

This dimension focuses on the promotion of collaborative school-family actions in the educational institution, although in combination with activities taking place outside of the school and training activities (community participation and family training, which we will discuss further in this work). Families act as volunteers in a wide variety of activities (school patrolling, student transport, classroom workshops, sporting activities, scholastic camp, fund collection, etc.) which are promoted and coordinated by teachers (Epstein et al., 2019) using distinct participation modalities, such as attendance, collaboration, or involvement in management and decision making (Consejo Escolar del Estado, 2014).

\section{Sense of Belonging}

Although research has demonstrated that the sense of belonging to a school is the driving force behind participation (Uslu and Gizir, 2017), few studies have analyzed how teachers contribute to fostering this participation by the families. Reference has been made to the sense of belonging and recognition by the educational community and how this can be promoted through a greater knowledge of the school, trust in the teaching staff, removal of myths and prejudices, meetings with families, satisfaction with the school activities carried out, etc. (Cheung et al., 2017). It is also related to positive communication with teachers (Anderson and Minke, 2007) and involvement in the home (Uslu and Gizir, 2017). Indeed, "Whereas most parents are reluctant to seek the help of professional counselors, they will approach their children's teachers in search of guidance or counseling for the problems that concern them" (Hornby, 2011, p. 37).

\section{Involvement in the Home}

The expression "family involvement" refers, on the one hand, to extra-scholastic, cultural, family leisure, and value-transmission activities (Consejo Escolar del Estado, 2014; Caldas and Cornigans, 2015) and, on the other hand, to parent expectations, homework supervision, promoting reading, and reserving the term "participation" to refer to school activities (Castro et al., 2015). Parental support in the home relies on teacher counseling to redirect and encourage the children's studies (Kurtulmus, 2016). It may be offered on an individual or a group manner, and requires the creation of effective, trust-based communicative 
processes (Hornby, 2011). All of this contributes to the creation of a sense of belonging to the community.

\section{AMPA (Parent Association) and School Board}

The legal model of joint responsibility regulated via the parent association (PA) and School Board contributes to improved performance; family participation; educational quality; and knowledge of citizen rights, responsibilities, and duties (Benner et al., 2016). It promotes aspects related to the school and the community, and its success is based in large part on collaboration, recognition, and dissemination of the same by the teacher (García-Sanz et al., 2020). However, although this model is quite extensive and has reached most schools, only a small minority of parents are actively involved (Hornby, 2011), usually as associates and not as managers, be it in the PA management team or as a School Board representative (García-Sanz et al., 2020).

\section{Community Participation}

Teachers, in collaboration with the PA and in support of a bidirectional relationship between schools and society, should know how to involve their students' families in cooperation with community/neighborhood organizations. This involves the use of external (libraries, parks, museums, etc.), leisure, volunteer, and solidarity action services, religious events, community associations, or strength-talent training (Epstein et al., 2019; Gahwaji, 2019; Garbacz et al., 2019). According to Severiens et al. (2014), these activities should be included in teacher training curriculums since community projects are more beneficial when they are directed at the entire school population, as opposed to those that are individualized and only from the school.

\section{Family Training}

Parental education helps contribute to school improvement. This school-based activity is often managed by PAs and tends to be directed at families, although recently, community training has also been promoted, with parents and teachers learning together (Tran, 2014; Hernández-Prados, 2019). This explains the close association between training, school activities, the PASchool Board, and community participation, since they often rely on municipal training offers or external professionals, especially in the case of public schools (Hernández-Prados et al., 2019).

Using the IMFIS-TP as a foundation, the following research question was proposed: How is it possible to validly and reliably assess the way and the degree to which teachers facilitate family participation in their children's schools? The purpose of the study is to create a multidimensional questionnaire directed at teachers that is based on the IMFIS-TP, which allows us to obtain information regarding the assistance offered by teachers so that parents may participate in the distinct dimensions making up family participation in education institutions. The questionnaire will be very useful to know where to direct the initial and continuous training of teachers.

\section{MATERIALS AND METHODS}

\section{Participants}

The invited population consisted of 542 teachers from 14 multicultural educational institutes in southeastern Murcia (Spain), where they teach Early Childhood, Primary, and Secondary Education. Of these, 225 teachers agreed to participate, resulting in a $95 \%$ confidence level and a 5\% sampling error.

\section{Instrument}

Based on the IMFIS-TP, an initial questionnaire was created with 11 socio-demographic questions and 91 items on teacher facilitation of family participation, grouped into seven dimensions: "Questionnaire on Family Involvement in School, Teacher-Promoter" (QFIS-TP). After performing an interjudge content validation with 5 university professors (experts in family-school relations and methodology) and the 14 management teams from the participating schools, the instrument kept the 11 socio-demographic questions, but the family participation items were reduced to 74 (Table $\mathbf{1}$ ).

The scale of items contains 5 degrees, except for item 74, which is dichotomous (Yes/No). In the following dimensions, namely communication with the school, involvement in the home, participation in the PA and school board, training, and all related to school facilitation for. .., interpretation of the scale is: 1 . Never/none; 2. Infrequently/few; 3. Sometimes/somewhat; 4. Often/considerably; 5. A lot/many. In the dimensions of Participation in school activities and Community participation, the scale ranges from: 1 . I don't know if they are carried out; 2 . I know of them; 3. I attend; 4. I collaborate, participating; 5. I am involved in their organization. Also, those referring to the Sense of belonging dimension are responded to using the following scale: 1. Completely disagree; 2. Disagree; 3. Indifferent; 4. Agree; 5. Completely agree.

\section{Procedure}

The validity of the content of the initial QFIS-TP was determined by sending an email to two types of judges (university educators and school management teams), permitting the modification of any items and elimination of others, when considered to be repetitive.

Upon validation, the QFIS-TP was applied to the professors on-line, using the survey platform of the University of Murcia. The research method was quantitative, non-experimental, descriptive and transversal, survey-type. Next, the data were analyzed using the IBM SPSS, v. 24 and IBM SPSS Amos, v.21 programs.

\section{ANALYSIS AND RESULTS}

\section{Exploratory Factorial Analysis}

To calculate the exploratory factorial analysis (EFA) using the main components extraction and Varimax rotation methods, the SPSS program was used, but first, the Spearman's correlation coefficient was obtained between all items of the instrument to 
TABLE 1 | QFIS-TP dimensions and items.

\section{A.Communication with the center}

Use an $\mathrm{X}$ to mark the frequency or degree to which, in your opinion, the content of each of the questions below arises, based on the indicated scale.

(1) I inform families of the importance of attending teacher-parent conferences when they are requested.

(2) I promote family requests of teacher-parent conferences throughout the school year.

(3) I urge families to attend group meetings of parents with the teacher, which are convened by the teaching staff.

(4) I encourage families, at least, to speak with the teacher in casual meetings at the entrance or exit of the school.

(5) I encourage families to hold meetings with the other teachers in the school, apart from their child's main teacher.

(6) In general terms, the school facilitates communication with the students' parents.

\section{B.Participation in school activities}

Indicate how you facilitate family involvement in the following activities, only in the cases in which they are organized by their child's educational institution, based on the indicated scale.

(7) In workshops in the classroom (on reading, crafts, cooking, etc.)

(8) In cultural activities (historic events, musical and ecological topics, traditions, international day of peace, grandparent's day, children's day, women's day, etc.)

(9) In sporting activities (soccer, basketball, judo, karate, etc. camps or exhibitions).

(10 At celebrations (Christmas, Carnival, end of year, etc.).

(11) In outings (to museums, monuments, other institutions, field trips, etc.).

(12) In service activities offered by the school (receiving children in classrooms before the school day begins, library, cafeteria, student transport, etc.)

(13) In work commissions created in the school (co-existence plan, school improvement plan, etc.)

(14) In economic collection commissions for classroom (gifts, costumes, classroom decorations, etc.)

(15) In processes used to assess the school (responding to questionnaires, using the suggestions box, presenting complaints and/or suggestions via PA or individually, etc.)

(16) In general, the school promotes family participation in the activities that it organizes.

\section{c.Sense of belonging}

Indicate your degree of agreement or disagreement with the following Statements, based on the indicated scale.

(17) I urge families to identify with the school's values, ideas, attitudes, goals, etc.

(18) I encourage families to feel that they are members of the school, so that they consider it to be their own.

(19) I promote the ideas in families that when a sporting, artistic or cultural team participates in a championship, contest or exhibition, it is their team.

(20) I talk with families to promote their trust in the educational work being carried out by teachers with their children, encouraging support of our decisions.

(21) I encourage families to feel attracted by the collaborative activities or experiences offered by the school.

(22) I help families perceive that their participation in the school makes them a part of the same.

(23) I encourage families to feel welcomed and integrated in the school community as of the onset of their child's schooling.

(24) I do everything possible to ensure that families feel satisfied with the education that the students receive.

(25) I guide families so that they feel free and can express their ideas, concern, suggestions, complaints, etc. in the school.

(26) I encourage families to recommend this school to others with school-aged children.

(27) Generally speaking, the school assists in creating a bond between it and families.

D.Involvement in the home

Mark the frequency or degree to which, in your opinion, the content of the statements presented below takes place, based on the indicated scale.

(28) I guide parents in speaking with their children about what they do in class.

(29) I encourage families to express their trust in their children.

(30) I inform families of their child's class attendance.

(31) I encourage families to take an interest in the educational tasks carried out by their children at home.

(32) I inform families of the importance of their children's study time organization.

(33) I encourage families to offer a good at-home study climate (to encourage studying, offer an appropriate study site without distractions, provide resources for learning, etc.)

(34) I inform families of the need to demonstrate their availability to their child's needs regarding their school work.

(35) I invite parents to congratulate their children when they complete their school work.

(36) I notify families of the importance that their children complete extra-curricular or complementary activities (languages, computer-based, music, dance, sports, academic activities, etc.)

(37) I communicate with families to promote the autonomy and responsibility of their children in their studies (encouraging them to be alert, but not to do their child's work or always be next to them when doing it).

(38) I speak to families so that they oversee the responsible use of computers, mobile phones, etc.

(39) I encourage families to engage in cultural activities (read, go to the cinema, theater, museums, trips, concerts, exhibitions, etc.)

(40) I encourage families to ensure that their children apply what they learn in school to their everyday lives.

(41) In general, the school facilitates parent involvement at home in the educational process of their children.

E.Involvement in the PA and the School Board

Mark the frequency or degree to which, in your opinion, the content of the following statements takes place, based on the indicated scale.

(42) I speak with families so that they are informed with regard to the organization and functioning of the PA.

(43) I encourage families to know the members of the PA Board of Directors.

(44) I help families gain knowledge regarding the activities organized by the PA. 
TABLE 1 | (Continued)

(45) I speak with parents so that they are informed and use the municipal bank of books in which the PA participates.

(46) I encourage families to consult information on the PA via websites, the social networks, etc.

(47) I invite families to participate in activities organized by the PA.

(48) I encourage families to form a part of the school's PA Board of Directors.

(49) I inform the PA of the importance that the association represents the interests of all of the school's families.

(50) Generally speaking, the school promotes parent participation in the PA.

(51) I help families to get to know the organization and functioning of the School Board.

(52) I encourage families to get to know their School Board representative.

(53) I invite families to be informed of the decisions made in School Board meetings.

(54) In encourage families to be informed as to the elections process of the School Board (calendar, candidates, voting procedure, etc.).

(55) I encourage families to participate in School Board elections.

(56) I encourage parents to apply for family representative positions in School Board elections.

(57) In general, the school promotes family participation in the School Board.

\section{F.Community participation}

Indicate how you facilitate family involvement in the following activities related to the community, based on the indicated scale.

(58) In collection activities (collection of food, clothes, caps, solidarity markets, etc.)

(59) In ecological activities (cleaning of waterways, march in support of the environment, environmental awareness programs, tree planting, etc.)

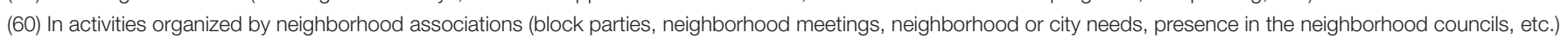

(61) In solidarity and volunteering activities (assistance to the elderly, the sick, those with limited resources, those who are alone, soup kitchens, etc.).

(62) In activities of the distinct religious communities.

(63) In activities directed at diversity awareness and integration (gender, abilities, cultural, ethnic background, etc.).

(64) In collaboration activities with youth associations promoting healthy leisure and free time.

(65) In general, the school promotes family participation in community activities.

G.Training

Mark the frequency or degree to which, in your opinion, the content of each of the statements below arises, based on the indicated scale.

(66) I guarantee that the families are informed of the training activities directed at the same that are organized by the education institution.

(67) I encourage families to attend training activities organized by the school.

(68) I speak with families to encourage their participation in training activities that are intended for them.

(69) I encourage parents to get involved in the management of training activities for families.

(70) I notify families of the importance of receiving appropriate training with regard to their children's educational process.

(71) I relate the training that is being offered by the school to an improvement in family-school relations.

(72) Generally speaking, the school facilitates participation in training activities intended for families.

(73) I need training in order to better facilitate family involvement in the education of their children.

(74) I am interested in attending training activities to improve family participation in the education of their children.

avoid problems of multicollinearity. No bivariate correlations exceeding 0.85 were found; therefore, it was not necessary to eliminate any item (Kline, 2005). In addition, the KaiserMeyer-Olkin (KMO) measure of sampling adequacy of 0.928 and the statistical significance of the Bartlett sphericity test (0.000) permit the EFA.

Coinciding with the dimensions of the IMFIS-TP, seven components were determined, having an explained variance of $64.70 \%$. This initial EFA consisted of all of the ordinal items of the questionnaire, except for those related to the teacher's perception of what the school does to facilitate family participation. With these items, a second EFA was created, since it was considered that its content did not specifically address teacher's attitudes and behaviors to collaborate in the improvement of family participation. Table 2 shows the rotated components matrix, ordered by size, referring to the first EFA.

As seen in Table 2, the first factor includes 14 items of the QFIS-TP dimension called involvement in the PA and School Board; the second 13 items are from the involvement in the home dimension; the third includes the 10 items corresponding to the sense of belonging dimension; the fourth consists of the 7 items from the community participation dimension; the fifth includes 9 items regarding the participation in school activities dimension; the sixth is made up of the 7 items from the training dimension; and the seventh and final factor includes the 5 items of the questionnaire regarding the communication with the school dimension.

Based on the results obtained in this EFA, it can be concluded that the QFIS-TP has not experienced any variations with regard to the assignment of items to each dimension in the content validation carried out by the experts and based on the premises of the IMFIS-TP. Therefore, the naming of the instrument's dimensions, as well as that of the items making up each of these, has been maintained with no modifications.

The second EFA, based on items related to the school's facilitation of families to improve the dimensions considered in the QFIS-TP, obtained a mean Kaiser-Meyer-Olkin sampling adequacy of 0.875 and a statistical significance according to the Bartlett's Sphericity test of 0.000 . The variance explained with Eigen values $>1$ was $55.95 \%$ (Table 3 ).

As we can observe, the eight items converge in one unique factor called: Facilitation of the school for family participation.

\section{Confirmatory Factorial Analysis}

Using the AMOS program, the IMFIS-TP was corroborated. To do so, the construct validity of the QFIS-TP was 
TABLE 2 | First EFA: rotated components matrix.

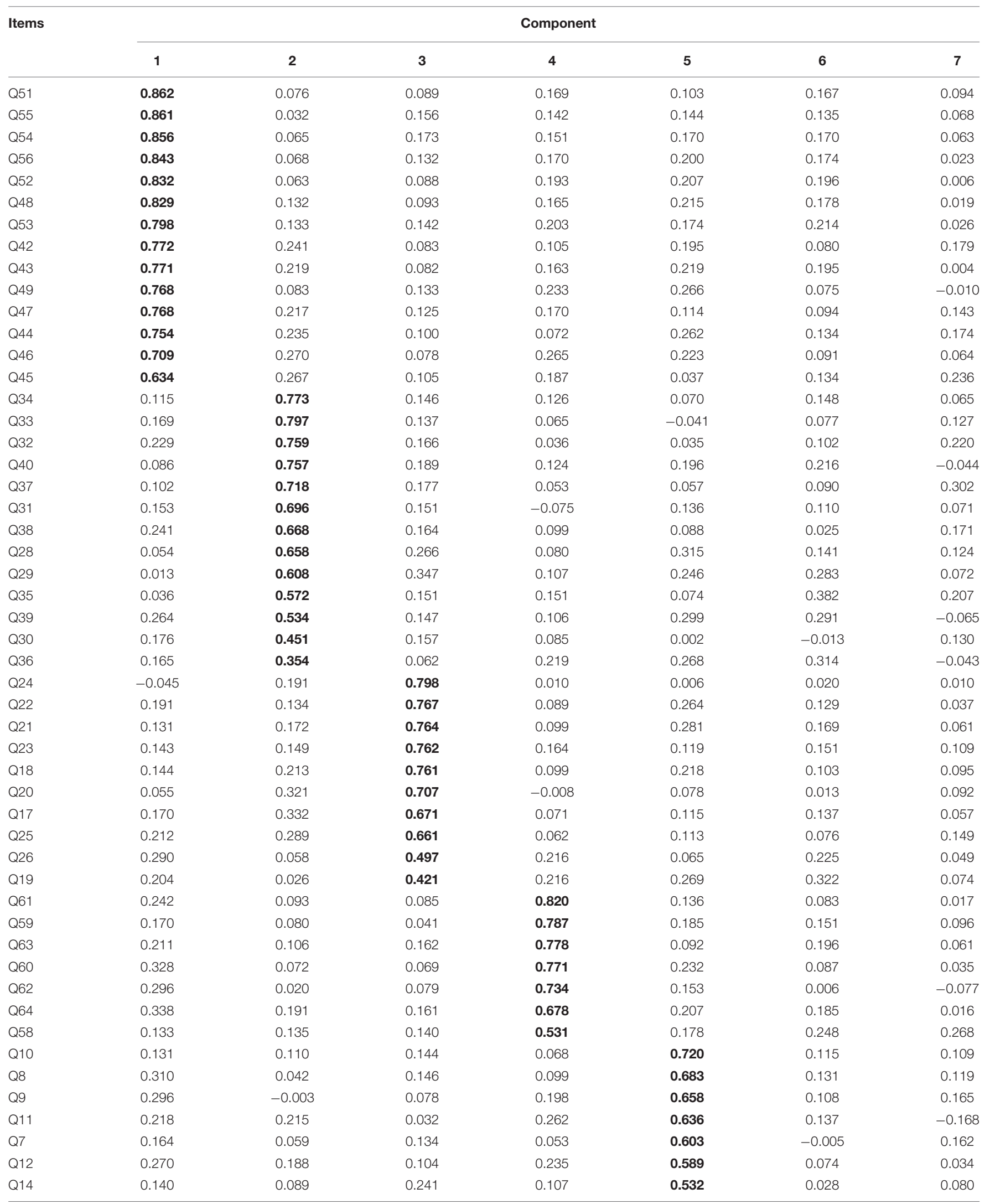


TABLE 2 | (Continued)

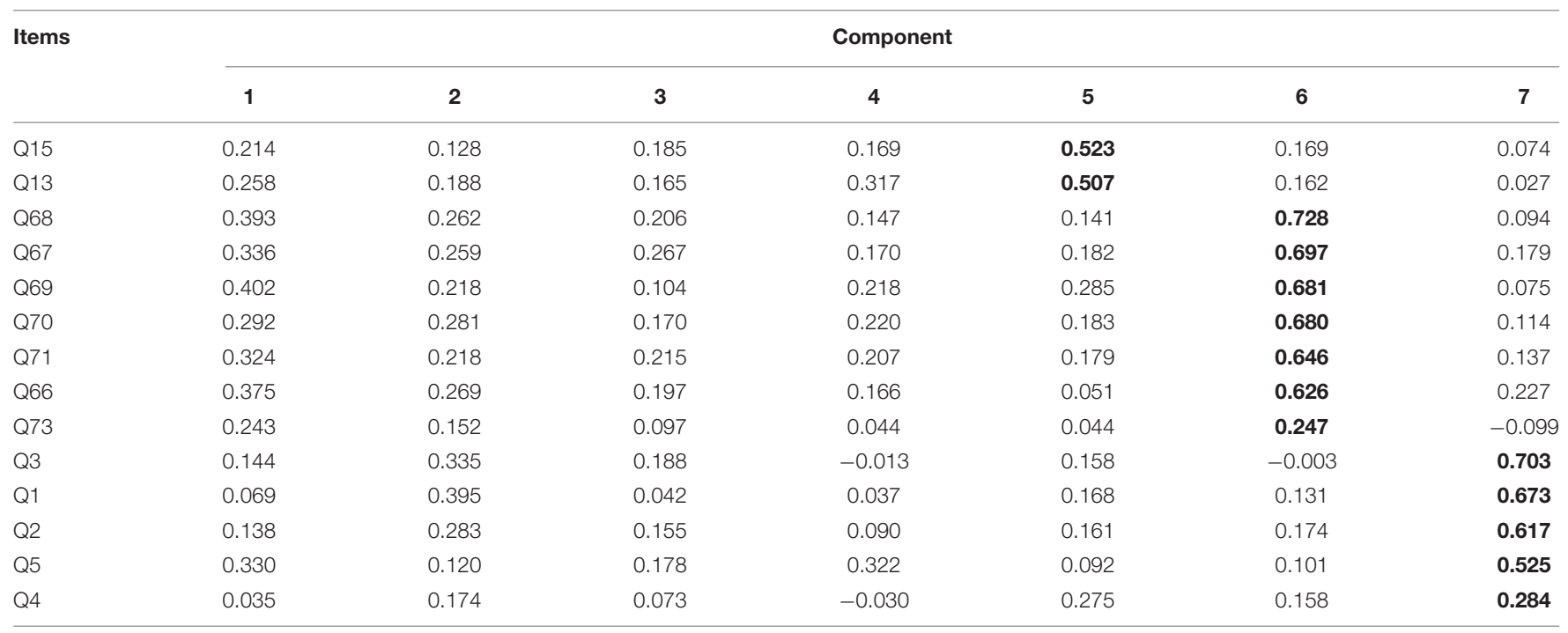

Bolded values are factor loadings of the items that make up each factor or component.

ratified through the calculation of a confirmatory factorial analysis (CFA) using the structural equations model. To offer more sense to the theoretical model, the involvement in the PA and the School Board was separated into two dimensions. Similarly, missing values and outliers were eliminated, despite the fact that there was no agreement regarding the removal of the latter (Aguinis et al., 2013). Therefore, cases in which the standardized observable variables exceeded a score of $|3|$ were excluded (Verdugo et al., 2008).

In accordance with the IMFIS-TP, the correlation between latent and observable variables, the measurement error of the same, and the covariance between the latent variables and measurement errors are represented graphically in Figure $\mathbf{1 .}$

The maximum likelihood method was used for model calculation, complying with the univariate normality criteria, having obtained values up to $|2|$ for asymmetry and up to $|7|$ for kurtosis (Curran et al., 1996).

Table 4 presents the regression coefficients (factorial loads) between the observable and latent variables, standard error (SE), critical ratio (CR), and the corresponding statistical significance

TABLE 3 | Second EFA: components matrix.

\begin{tabular}{lc}
\hline Items & Component \\
\cline { 2 - 2 } & \multicolumn{1}{c}{} \\
\hline Q27 & 0.828 \\
Q41 & 0.804 \\
Q57 & 0.784 \\
Q50 & 0.737 \\
Q65 & 0.729 \\
Q16 & 0.715 \\
Q72 & 0.707 \\
Q6 & 0.667
\end{tabular}

(p). Likewise, it indicates the standardized regression coefficients between the observable and latent variables. It may be observed that all of the pairs are significant, with $\alpha=0.01$. Likewise, in all cases, the standardized regression coefficients exceed the typical value of the effect size $(r \geq 0.3)$, as determined by Cohen (1988).

Table 5 reveals the covariance coefficients between the latent variables and between the measurement errors of the observable variables, the $\mathrm{SE}, \mathrm{CR}$, statistical significance $(p)$, and the respective standardized regression coefficients. As seen, the relationship between $84.62 \%$ of the pairs is significant at $\alpha=0.01$, whereas the relationship between the remaining $15.38 \%$ is statistically significant at $\alpha=0.05$. Likewise, the correlation coefficients reach (approximately) or exceed, in $79.49 \%$ of the cases, the typical value of the effect size $(r \geq 0.3)$ as established by Cohen (1988).

In accordance with $\mathrm{Hu}$ and Bentler (1998), various index types have been used to assess the fit of the model: standardized Chi square or the relative Chi square over degrees of freedom (CMIN/DF), included in the measures of goodness of fit; comparative fit index (CFI), framed within the incremental fit measures; and the root mean square error of approximation (RMSEA), included in the absolute goodness of fit measures. Table 6 indicates the values obtained and those desired, according to the classification established by distinct authors $(\mathrm{Hu}$ and Bentler, 1998; Lévy and Varela, 2003; Hair et al., 2008; Cupani, 2012).

With these referents (Table 6), it may be affirmed that the IMFIS-TP has acceptable fit indices between the theoretical structure of the model and the empirical results obtained.

\section{Reliability of the Questionnaire}

To obtain the reliability of the QFIS-TP, once again, the SPSS program was used. This psychometric property, both globally and by dimensions, was calculated using the 


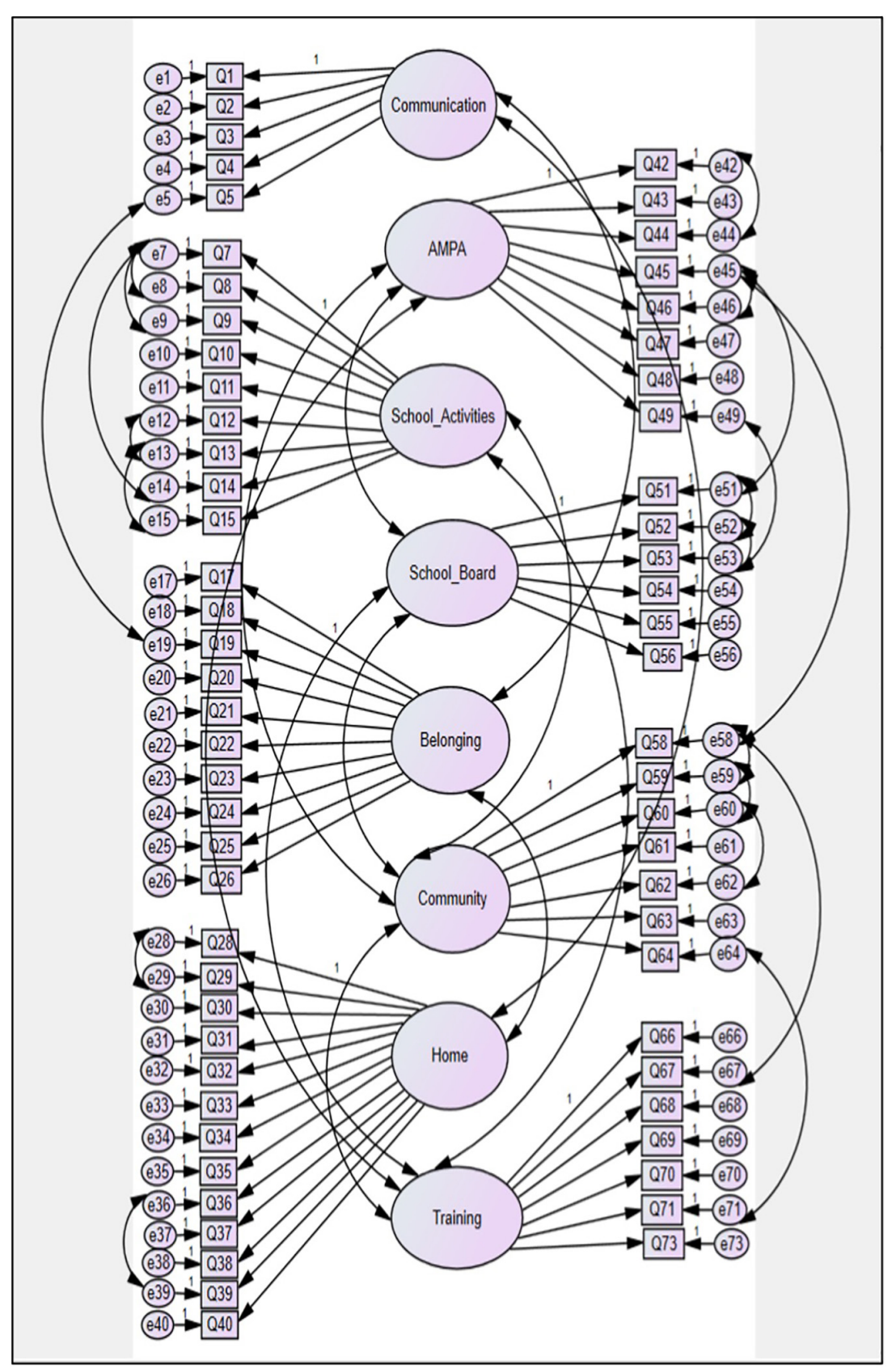

FIGURE 1 | Structural equations model of the QFIS-TP.

Cronbach's alpha dimension $(\alpha)$ and McDonald's omega $(\Omega)$. Table 7 shows the satisfactory indices of internal consistency (DeVellis, 2003), since all of the dimensions exceeded the value of 0.7 .

All of the items complied with the corrected item-total correlation; thus it was not necessary to eliminate any of them, either in the QFIS-TP or in the dimensions making up the same. The dimension having the lowest reliability was that of family communication with the school, and the most consistent one was family involvement in the PA and School Board.

\section{DISCUSSION}

This study confirms that the psychometric quality of the QFIS-TP, adjusted to the theoretical approach of the IMFIS$\mathrm{TP}$, is satisfactory. So, the seven dimensions making it up explain a variance of $64.70 \%$, having a high reliability, without modifications in the location of the items with respect to the model. However, the results of the CFA reveal that the octodimensional structure is best, dividing PA and the School Board into two dimensions, given that they 
TABLE 4 | Regression coefficients and standardized regression coefficients between observable and latent variables.

\begin{tabular}{|c|c|c|c|c|c|c|}
\hline & \multirow[t]{2}{*}{$\begin{array}{l}\text { Relationship between } \\
\text { and latent variables }\end{array}$} & \multicolumn{4}{|c|}{ Regression weights } & \multirow{2}{*}{$\begin{array}{c}\begin{array}{c}\text { Standardized } \\
\text { regression weights }\end{array} \\
\text { Estimate }\end{array}$} \\
\hline & & Estimate & SE & C.R. & $\mathbf{P}$ & \\
\hline Q5 & Communication & 1.312 & 0.197 & 6.674 & $* \star \star$ & 0.535 \\
\hline Q4 & Communication & 1.253 & 0.253 & 4.959 & $* \star \star$ & 0.396 \\
\hline Q3 & Communication & 1.340 & 0.149 & 9.000 & 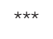 & 0.771 \\
\hline Q14 & School_Activities & 1.225 & 0.238 & 5.149 & $* * \star$ & 0.482 \\
\hline Q13 & School_Activities & 1.528 & 0.294 & 5.200 & 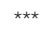 & 0.635 \\
\hline Q12 & School_Activities & 1.509 & 0.287 & 5.255 & $* \star \star$ & 0.650 \\
\hline Q11 & School_Activities & 1.718 & 0.320 & 5.377 & $* \star \star$ & 0.689 \\
\hline Q10 & School_Activities & 1.218 & 0.226 & 5.393 & 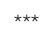 & 0.695 \\
\hline Q66 & Training & 1.000 & & & & 0.775 \\
\hline Q67 & Training & 1.104 & 0.081 & 13.548 & $* \star \star$ & 0.857 \\
\hline Q68 & Training & 1.290 & 0.092 & 13.961 & $* \star \star$ & 0.893 \\
\hline Q69 & Training & 1.321 & 0.099 & 13.342 & $* \star *$ & 0.862 \\
\hline Q70 & Training & 1.099 & 0.090 & 12.248 & 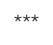 & 0.806 \\
\hline Q71 & Training & 1.046 & 0.089 & 11.752 & 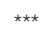 & 0.772 \\
\hline Q22 & Belonging & 1.340 & 0.126 & 10.598 & 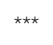 & 0.835 \\
\hline Q21 & Belonging & 1.321 & 0.122 & 10.827 & 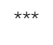 & 0.856 \\
\hline Q20 & Belonging & 0.994 & 0.115 & 8.633 & 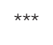 & 0.666 \\
\hline Q19 & Belonging & 0.897 & 0.152 & 5.897 & 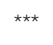 & 0.439 \\
\hline Q33 & Home & 0.894 & 0.095 & 9.423 & 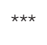 & 0.759 \\
\hline Q32 & Home & 0.894 & 0.092 & 9.700 & 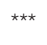 & 0.786 \\
\hline Q31 & Home & 0.769 & 0.093 & 8.270 & 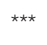 & 0.653 \\
\hline Q30 & Home & 0.733 & 0.103 & 7.128 & 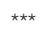 & 0.553 \\
\hline Q29 & Home & 1.148 & 0.083 & 13.907 & 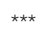 & 0.760 \\
\hline Q28 & Home & 1.000 & & & & 0.663 \\
\hline Q35 & Home & 0.924 & 0.105 & 8.836 & 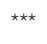 & 0.704 \\
\hline Q36 & Home & 0.941 & 0.151 & 6.244 & 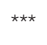 & 0.480 \\
\hline Q37 & Home & 0.960 & 0.098 & 9.757 & 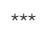 & 0.791 \\
\hline Q38 & Home & 1.061 & 0.122 & 8.687 & 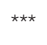 & 0.690 \\
\hline Q39 & Home & 1.106 & 0.148 & 7.491 & 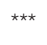 & 0.585 \\
\hline Q40 & Home & 1.235 & 0.134 & 9.226 & 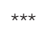 & 0.740 \\
\hline Q45 & AMPA & 0.882 & 0.085 & 10.341 & $* \star \star$ & 0.651 \\
\hline Q46 & AMPA & 1.068 & 0.080 & 13.393 & 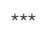 & 0.786 \\
\hline Q44 & AMPA & 1.010 & 0.054 & 18.805 & $* \star *$ & 0.834 \\
\hline Q43 & AMPA & 1.133 & 0.072 & 15.718 & 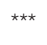 & 0.866 \\
\hline Q42 & AMPA & 1.000 & & & & 0.840 \\
\hline Q47 & AMPA & 1.188 & 0.070 & 16.868 & $* \star *$ & 0.901 \\
\hline Q48 & AMPA & 1.329 & 0.078 & 17.121 & 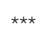 & 0.908 \\
\hline
\end{tabular}


TABLE 4 | (Continued)

\begin{tabular}{|c|c|c|c|c|c|c|}
\hline & \multirow{2}{*}{$\begin{array}{l}\text { Relationship between } \\
\text { and latent variables }\end{array}$} & \multicolumn{4}{|c|}{ Regression weights } & \multirow{2}{*}{$\begin{array}{c}\text { Standardized } \\
\text { regression weights } \\
\text { Estimate }\end{array}$} \\
\hline & & Estimate & SE & C.R. & $\mathbf{P}$ & \\
\hline Q49 & AMPA & 1.262 & 0.085 & 14.842 & 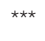 & 0.837 \\
\hline Q53 & School_Board & 1.000 & 0.060 & 16.611 & $\star \star \star *$ & 0.855 \\
\hline Q54 & School_Board & 1.152 & 0.051 & 22.418 & 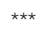 & 0.974 \\
\hline Q52 & School_Board & 1.059 & 0.047 & 22.763 & $\star \star \star *$ & 0.887 \\
\hline Q51 & School_Board & 1.000 & & & & 0.869 \\
\hline Q55 & School_Board & 1.177 & 0.056 & 20.966 & $\star \star \star *$ & 0.949 \\
\hline Q56 & School_Board & 1.191 & 0.057 & 20.904 & $\star * \star$ & 0.948 \\
\hline Q61 & Community & 1.751 & 0.207 & 8.447 & $\star \star \star *$ & 0.840 \\
\hline Q60 & Community & 1.530 & 0.188 & 8.125 & 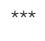 & 0.786 \\
\hline Q59 & Community & 1.554 & 0.168 & 9.238 & 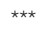 & 0.739 \\
\hline Q62 & Community & 1.378 & 0.182 & 7.563 & 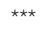 & 0.701 \\
\hline Q63 & Community & 1.771 & 0.209 & 8.471 & 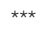 & 0.845 \\
\hline Q64 & Community & 1.611 & 0.195 & 8.274 & 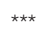 & 0.795 \\
\hline Q58 & Community & 1.000 & & & & 0.555 \\
\hline Q73 & Training & 0.466 & 0.105 & 4.445 & 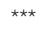 & 0.323 \\
\hline
\end{tabular}

*** Statistical significance of the regression between each item and the assigned construct.

refer to distinct representation organisms (García-Sanz et al., 2020).

The results of the structural equations model have offered covariance between measurement errors of some of the observable variables. However, while this covariance is inevitable, it may be considered appropriate (Landis et al., 2009). In this case, although the reduction of the affected items is similar, they are necessary to confirm the specified theoretical model.

So, based on the results obtained in each of the QFIS-TP subscales, it is evident that the "promoter of communication with families" and "promoter of sense of belonging" roles are theoretical and statistically related (Tran, 2014), and demonstrate a high internal consistency, although covariance has been registered between the measurement error of the variables, encourage meetings with other teachers (Q5), and defense of the school in competitions (Q19). On the other hand, the teacher's role as "promoter of school activities" has produced diverse covariance between measurement errors, suggesting that for teachers, the actions are generalized, categorically hindering their definition. So, we believe that it is necessary to offer more specialized training with this respect, since studies clearly differentiate between classroom (Q7), cultural (Q8), sporting (Q9), and fund collection support (Q14) activities (Hornby, 2011; Epstein et al., 2019). Likewise, although work by commissions (Q13) as a resource may be useful in service (Q12) and school evaluation (Q15) activities, they have specifications of differentiated contents and they operate on different planes. In the first case, in the design of plans and in the following, in implementation and participation. However, Lingard et al. (2014) positively assessed family inclusion in work commissions for educational assessment and restructuring, since they promote active listening and multidirectional dialogue, despite teachers' difficulties in taking advantage of the parents' opinions.

As for "promoting involvement in the home," covariance has been identified in the following measurement errors: Q28-Q29 and Q36-Q39. While positive parent-child relationships are sustained by communication and trust (Q28), this latter should not remain implicit, but rather, must be manifested (Q29) (Ebbert et al., 2019). On the other hand, a confusion between extracurricular (Q36) and cultural (Q39) activities has been confirmed, treating them as synonymous (Ladky and Peterson, 2008), when in fact, the former are academic and individualistic activities, while the latter are collective and are linked to family leisure (Hernández-Prados and Álvarez-Muñoz, 2019).

The subscale to promote the PA is not a generalized action of the teacher consisting of attending meetings (Garbacz et al., 2019), but, on the contrary, it consists of diverse aspects, since helping families getting familiarized with the PA as an organization (Q42) is different from informing them of activities offered to the families (Q44), just like encouraging the use of a banks of books (Q45) and checking the PA website (Q46). On the other hand, according to García-Sanz et al. (2020), the School Board is not as well-known as the PA and requires that teachers promote the knowledge of their representatives (Q52), but also, their organization and functioning (Q51) and the decisions that they make (Q53). Similar items have been proposed by Yulianti et al. (2019). Finally, the relationship between both dimensions reveals itself theoretically (Consejo Escolar del Estado, 2014; Epstein et al., 2019) in the covariance between measurement errors (Q45-Q51 and Q49-Q53), even though each was saturated in different factors.

Seventh, the teacher as "promoter of community participation" is recognized in educational policy, but has 
TABLE 5 | Covariance and correlation between latent and observable variables.

\begin{tabular}{|c|c|c|c|c|c|c|}
\hline \multicolumn{2}{|c|}{$\begin{array}{c}\text { Relationship between latent } \\
\text { variables and between measurement errors }\end{array}$} & \multicolumn{4}{|c|}{ Covariance } & \multirow{2}{*}{$\begin{array}{c}\text { Correlation } \\
\text { Estimate }\end{array}$} \\
\hline & & Estimate & SE & C.R. & $P$ & \\
\hline AMPA & Community & 0.264 & 0.056 & 4.735 & $* \star \star$ & 0.449 \\
\hline Training & Community & 0.233 & 0.049 & 4.756 & $* * *$ & 0.484 \\
\hline School_Board & Community & 0.275 & 0.062 & 4.450 & $\star \star \star \star ~$ & 0.397 \\
\hline School_Activities & Community & 0.122 & 0.035 & 3.464 & $* \star \star$ & 0.367 \\
\hline Training & AMPA & 0.399 & 0.064 & 6.209 & $\star * \star$ & 0.587 \\
\hline AMPA & School_Board & 0.899 & 0.111 & 8.098 & $* * \star$ & 0.917 \\
\hline Training & School_Board & 0.433 & 0.072 & 5.987 & $* \star \star$ & 0.540 \\
\hline School_Activities & Training & 0.113 & 0.033 & 3.392 & $* * \star$ & 0.292 \\
\hline Communication & Home & 0.127 & 0.023 & 5.433 & $* * *$ & 0.646 \\
\hline Communication & Belonging & 0.108 & 0.020 & 5.313 & 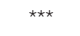 & 0.607 \\
\hline Belonging & Home & 0.149 & 0.027 & 5.603 & $* * *$ & 0.653 \\
\hline e8 & e7 & 0.305 & 0.065 & 4.700 & $* * *$ & 0.386 \\
\hline e9 & e7 & 0.222 & 0.066 & 3.351 & 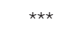 & 0.254 \\
\hline e13 & e12 & 0.281 & 0.075 & 3.749 & $* * *$ & 0.321 \\
\hline e36 & e39 & 0.193 & 0.051 & 3.760 & $* * *$ & 0.291 \\
\hline e42 & e44 & 0.138 & 0.031 & 4.416 & $* * *$ & 0.384 \\
\hline e51 & e52 & 0.139 & 0.028 & 4.968 & $\star * \star$ & 0.382 \\
\hline e58 & e59 & 0.256 & 0.065 & 3.931 & $\star \star \star \star ~$ & 0.289 \\
\hline e59 & e60 & 0.144 & 0.049 & 2.928 & 0.003 & 0.203 \\
\hline e60 & e62 & 0.332 & 0.063 & 5.257 & $\star \star \star \star ~$ & 0.475 \\
\hline e14 & e7 & 0.279 & 0.084 & 3.324 & $* * *$ & 0.226 \\
\hline e5 & e19 & 0.188 & 0.052 & 3.574 & $* * *$ & 0.277 \\
\hline e15 & e13 & 0.156 & 0.069 & 2.246 & 0.025 & 0.168 \\
\hline e28 & e29 & 0.155 & 0.025 & 6.138 & $* * *$ & 0.557 \\
\hline e58 & e45 & 0.121 & 0.055 & 2.182 & 0.029 & 0.133 \\
\hline e58 & e67 & 0.189 & 0.038 & 4.929 & $\star * \star \star$ & 0.395 \\
\hline e64 & e71 & 0.139 & 0.043 & 3.249 & 0.001 & 0.273 \\
\hline e45 & e51 & 0.135 & 0.038 & 3.530 & $\star \star \star *$ & 0.236 \\
\hline e53 & e52 & 0.120 & 0.028 & 4.249 & $* \star * *$ & 0.310 \\
\hline e49 & e53 & 0.083 & 0.036 & 2.313 & 0.021 & 0.169 \\
\hline e45 & e46 & 0.167 & 0.054 & 3.116 & 0.002 & 0.233 \\
\hline
\end{tabular}

*** Statistical significance of the regression between each item and the assigned construct.

barely been developed in Spain, justifying the diversity of covariance between measurement errors. While neighborhood activities (Q60) may be ecological (Q59) or religious (Q62), according to Yulianti et al. (2019), these have been differentiated between, since they can be carried out by other associations. On the other hand, collection activities (Q58) are civic and solidarity-based, being external to the school environment, whereas textbook collection and distribution (Q45) is internal, and ecological activities (Q59) do not pursue collection, but rather, active involvement. All of these "are important with a strong range of institutions (religious, recreational, corporate, and library) that are linked to maintain stability, cohesion, and well-being of the community" (Gahwaji, 2019, p. 11).

TABLE 6 | Goodness of fit indices of the IMFIS-TP.

\begin{tabular}{lcc}
\hline Index & Desired value & Obtained value \\
\hline CMIN/DF & Between 1 and 5 & 1.88 \\
CFI & $\geq 0.9$ & 0.90 \\
RMSEA & $<0.08$ & 0.07
\end{tabular}

Finally, "promoting family training" has covariance of measurement errors with variables from the previous subscale (Q64-Q71 and Q58-Q67), since according to IMFIS-TP, they are related to one another. In fact, taking advantage of free time (Q64) is one of the recurrent topics of the training offer (Q71) (Hernández-Prados and Álvarez-Muñoz, 2019).

TABLE 7 | Overall reliability of the questionnaire and reliability by dimensions.

\begin{tabular}{lcc}
\hline Dimensions & Cronbach's $\alpha$ & McDonald's $\boldsymbol{\Omega}$ \\
\hline Overall & 0.975 & 0.982 \\
Communication with the school & 0.731 & 0.703 \\
Participation in school activities & 0.875 & 0.840 \\
Sense of belonging & 0.915 & 0.899 \\
Involvement in the home & 0.921 & 0.904 \\
Involvement in the PA and School Board & 0.975 & 0.959 \\
Community Participation & 0.874 & 0.889 \\
Training & 0.916 & 0.816
\end{tabular}


The creation of this instrument can allow us to know the reality of the teacher and promote measures for training from the university (initial education), teacher training centers, and internal training promoted by the school (permanent training).

Based on all of this, the study has demonstrated that the techniques developed to assess the structural equations model have a confirmatory bias. Therefore, although the proposed model has an acceptable fit, the researcher has not tested it, but rather, has only confirmed that it is one of the various potential models (Cupani, 2012). As for the study's limitations, although the QFIS-TP suitably fits the IMFIS-TP and permits knowledge of the level of competency of the teachers as promoters of family participation, future works should expand and diversify the sample of teachers, both in a national and international scope. Longitudinal studies are needed, in contrast with the qualitative studies, to identify other actions that teachers promote and that may not have been considered in the QFIS-TP. All of this will favor the creation of instruments that offer knowledge having a better fit with the teacher's reality and will promote training measures from the university (initial education), the teacher training centers, and internal training promoted by the school. It would also be interesting to determine the teacher's level of belonging to the school, since they cannot promote this if they themselves do not experience it. All of this suggests that this emerging field demands further research to help improve family participation.

\section{REFERENCES}

Anderson, K. J., and Minke, K. M. (2007). Parent involvement in education: toward an understanding of parents' decision making. J. Educ. Res. 100, 311-323. doi: 10.3200/JOER.100.5.311-323

Aguinis, H., Gottfredson, R. K., and Joo, H. (2013). Best-practice recommendations for definind, identifying, and handling outliers. Organ. Res. Methods 16, 270301. doi: $10.1177 / 1094428112470848$

Benner, A. D., Boyle, A. E., and Sadler, S. (2016). Parental involvement andadolescents' educational success: The roles of prior achievement andsocioeconomic status. J. Youth Adolesc. 45, 1053-1064. doi: 10.1007/s10964-016-0431-4

Caldas, S. J., and Cornigans, L. (2015). Race/ethnicity and social capital among middle-and upper-middle-class elementary school families: a structural equation model. Sch. Comm. J. 25, 137-156.

Castro, M., Expósito-Casas, E., López-Martín, E., Lizasoain, L., Navarro-Asencio, E., and Gaviria, J. L. (2015). Parental involvement on student academic achievement: A meta-analysis. Educ. Res. Rev. 14, 33-46. doi: 10.1016/j.edurev. 2015.01.002

Cheung, C. K., Cheung, H. Y., and Hue, M. T. (2017). Educational contributions to students belongingness to the society, neighbourhood, school and family. Internat. J. Adolesc. Youth 22, 226-237. doi: 10.1080/02673843.2016.11 57827

Cohen, J. (1988). Statistical Power Analysis for the Behavioral Sciences. 2nd ed. New York, NY: Academic Press.

Consejo Escolar del Estado (2014). La participación de las familias en la educación escolar. Madrid: Subdirección General de Documentación y Publicaciones.

Cupani, M. (2012). Análisis de ecuaciones estructurales: conceptos, etapas de desarrollo y un ejemplo de aplicación. Revista Tesis 1, 186-199.

Curran, P. J., West, S. G., and Finch, J. F. (1996). The robustness of test statistics to nonnormal- ity and specification error in confirmatory factor analysis. Psychol. Methods 1, 16-29. doi: 10.1037/1082-989X.1.1.16

\section{DATA AVAILABILITY STATEMENT}

The data are available and will soon appear in the Centro de Investigaciones Sociológicas (CIS) database called ARChivo de Estudios Sociales (ARCES) which can be accessed through http://www.arces.cis.es/arces.jsp.

\section{AUTHOR CONTRIBUTIONS}

MGO: exhaustive review of theoretical contributions, active collaboration in the construction of the questionnaire, general and specific proposals regarding the methodology, writing of the discussion section, and conclusions based on the results obtained. JP and MG-S: methodological development and analysis of results. MH-P: review for the theoretical basis, discussion, and conclusions. All authors contributed to the article and approved the submitted version.

\section{FUNDING}

This work was supported by the MINECO (Ministerio de Economía, Industria y Competitividad) under Grant number EDU2016-77035-R and the under Grant number PID2020113505RB-I00 funded by MCIN/AEI/ 10.13039/501100011033 (Ministerio de Ciencia e Innovación/ Agencia Estatal de Investigación).

Dettmers, S., Yotyodying, S., and Jonkmann, K. (2019). Antecedents and outcomes of parental homework involvement: how do family-school partnerships affect parental homework involvement and student outcomes? Front. Psychol. 10:1048. doi: 10.3389/fpsyg.2019.01048

DeVellis, R. F. (2003). Scale development: Theory and applications. 2nd ed. Thousand Oaks, CA: Sage.

Ebbert, A. M., Infurna, F. J., and Luthar, S. S. (2019). Mapping developmental changes in perceived parent-adolescent relationship quality throughout middle school and high school. Dev. Psychopathol. 31, 1541-1556. doi: 10.1017/ S0954579418001219

Epstein, J. L. (2011). School, Family and Community Partnerships. Preparing Educators and Improving Schools. Boulder: WESTVIEW Press.

Epstein, J. L., Sanders, M. G., Sheldon, S. B., Simon, B. S., Salinas, K. C., Jansorn, N. R., et al. (2019). School, family, and community partnerships: Your handbook for action. Thousand Oaks, CA: Corwin press.

Erdener, M. A. (2016). Principals' and Teachers' Practices about Parent Involvement in Schooling. Univ. J. Educ. Res. 4, 151-159. doi: 10.13189/ujer. 2016.041319

Europe Strategy 2020 (2015). Unión por la innovación. Luxemburgo: Oficina de Publicaciones Oficiales de las Comunidades Europeas.

European Commission (2000). Informe europeo sobre la calidad de la educación escolar. Dieciséis indicadores de calidad. Luxemburgo: Oficina de Publicaciones Oficiales de las Comunidades Europeas.

European Commission (2005). Propuesta de Decisión del Parlamento Europeo y del Consejo de Europa que dé luz verde al programa "Ciudadanos para Europa" durante el periodo 2007-2013 para promover una ciudadanía europea activa. Luxemburgo: Oficina de Publicaciones Oficiales de las Comunidades Europeas.

Gahwaji, N. M. (2019). The implementation of the epstein's model as a partnership framework at saudi kindergartens. J. Coll. Teach. Learn. 16, 11-20. doi: 10. 19030/tlc.v16i2.10318

García-Sanz, M. P., Hernández-Prados, M. A., Galián-Nicolás, B., and BelmonteAlmagro, M. L. (2020). Docentes, familias y órganos de representación escolar. Estudios Educ. 38, 125-144. 
Garbacz, S. A., Hall, G. J., Young, K., Lee, Y., Youngblom, R. K., and Houlihan, D. D. (2019). Validation study of the family involvement questionnaireelementary version with families in belize. Assess. Effect. Interv. 45, 73-80. doi: $10.1177 / 1534508419862857$

Gomariz, M. A., Hernández-Prados, M. A., García-Sanz, M. P., and Parra, J. (2017). Tejiendo puentes entre la escuela y la familia. El papel del docente. Bordón Rev. Pedagog. 68, 41-57. doi: 10.13042/Bordon.2016.49832

Hair, J. F., Anderson, R. E., Tatham, R. L., and Black, W. C. (2008). Análisis multivariante. 5th ed. Madrid: Prentice Hall.

Hernández-Prados, M. A. (2019). "El encuentro formativo de las familias y docentes. Un espacio de colaboración," in Formar para Transformar. Cambio Social y Profesiones Educativas, ed. J. Vera-Vila (Granada: GEU), 267-270.

Hernández-Prados, M. A., and Álvarez-Muñoz, J. S. (2019). Family leisure and academic achievement. Perception of the families. Ital. J. Educ. Res. 86-105. Available online at: https://ojs.pensamultimedia.it/index.php/sird/article/view/ 3685

Hernández-Prados, M. A., García-Sanz, M. P., Galián-Nicolás, B., and BelmonteAlmagro, M. L. (2019). Implicación de familias y docentes en la formación familiar. Rev. Electrón. Interuniv. Formación Profesorado 22, 61-75. doi: 10. 6018/reifop.388971

Hornby, G. (2011). Parental involvement in childhood education: Building effective school-family partnerships. New York, NY: Springer Science \& Business Media. doi: 10.1007/978-1-4419-8379-4

Hu, L. T., and Bentler, P. M. (1998). Fit indices in covariance structure modeling: Sensitivity to underparameterized model misspecification. Psycholog. Methods 3, 424-453. doi: 10.1037/1082-989X.3.4.424

Kline, R. B. (2005). Principies and practice of structural equation modeiing. 2 nd ed. New York, NY: Guilford.

Kurtulmus, Z. (2016). Analyzing parental involvement dimensions in early hildhood education. Educ. Res. Rev. 11, 1149-1153. doi: 10.5897/ERR2016. 2757

Ladky, M., and Peterson, S. S. (2008). Successful practices for immigrant parent involvement: An Ontario perspective. Multicult. Perspect. 10, 82-89. doi: 10. 1080/15210960801997932

Landis, R., Edwards, B. D., and Cortina, J. (2009). "Correlated residuals among items in the estimation of measurement models," in Statistical and methodological myths and urban legends: Doctrine, verity, and fable in the organizational and social sciences, eds C. E. Lance and R. J. Vandenberg (Milton Park: Routledge), 195-214.

Lévy, J. P., and Varela, J. (2003). Análisis multivariante para Ciencias Sociales. Madrid: Pearson-Prentice Hall.

Lingard, B., Baroutsis, A., and Sellar, S. (2014). Learning Commission Report: Connecting schools with communities. Brisbane: The University of Queensland.

Maxwell, B., and Staring, F. (2018). Better learning for Europe's young people: developing coherent quality assurance strategies for school education. Bruselas: Comisión Europea.

Organisation for Economic Co-operation and Development [OECD] (2011). When students repet grades or are transferred out of school: what does it mean for education systems? PISA Focus 6, 1-4.
Organisation for Economic Co-operation and Development [OECD] (2012). Let's Read Them a Story! The Parent Factor in Education. Paris: PISA, OECD Publishing.

Organisation for Economic Co-operation and Development [OECD] (2014). Panorama de la educación 2014. Paris: PISA, OECD Publishing.

Severiens, S., Wolff, R., and van Herpen, S. (2014). Teaching for diversity: a literature overview and an analysis of the curriculum of a teacher training college. Eur. J. Teach. Educ. 37, 295-311. doi: 10.1080/02619768.2013.845166

Spanish Strategy of Science and Technology and of Innovation [EECTI] (2012). https://www.ciencia.gob.es/Estrategias-y-Planes/Estrategias/EstrategiaEspanola-de-Ciencia-Tecnologia-e-Innovacion-2021-2027.html;jsessionid= D52CD16D241D56361C80ED233EAF4A8D.2

Tran, Y. (2014). Addressing reciprocity between families and schools: Why these bridges are instrumental for students' academic success. Improv. Sch. 17, 18-29. doi: $10.1177 / 1365480213515296$

Uslu, F., and Gizir, S. (2017). School belonging of adolescents: The role of teacherstudent relationships, peer relationships and family involvement. Educ. Sci. 17, 63-82. doi: 10.12738/estp.2017.1.0104

Verdugo, M. A., Crespo, M., Badía, M., and Arias, B. (2008). Metodología en la investigación sobre discapacidad. Introducción al uso de las ecuaciones estructurales. Paper presented at the VI Seminario Científico SAID, Salamanca, june, 5 and 6 .

Vogels, R. (2002). Ouders bij de Les. Betrokkenheid van Ouders bij de School van hun Kind. Den Haag: Sociaal Cultureel Planbureau.

Walker, J. M. T., Wilkins, A. S., Dallaire, J. R., Sandler, H. M., and HooverDempsey, K. V. (2005). Parental involvement: Model revision through scale development. Elem. Sch. J. 106, 85-105. doi: 10.1086/499193

Yulianti, K., Denessen, E., Droop, M., and Veerman, G. (2019). Transformational Leadership for Parental Involvement: How Teachers Perceive School Leadership Practices to Promote Parental Involvement in Children's Education". Leadership Policy Sch. 18, 1-16. doi: 10.1080/15700763.2019. 1668424

Conflict of Interest: The authors declare that the research was conducted in the absence of any commercial or financial relationships that could be construed as a potential conflict of interest.

Publisher's Note: All claims expressed in this article are solely those of the authors and do not necessarily represent those of their affiliated organizations, or those of the publisher, the editors and the reviewers. Any product that may be evaluated in this article, or claim that may be made by its manufacturer, is not guaranteed or endorsed by the publisher.

Copyright (C) 2022 Gomariz, Parra, García-Sanz and Hernández-Prados. This is an open-access article distributed under the terms of the Creative Commons Attribution License (CC BY). The use, distribution or reproduction in other forums is permitted, provided the original author(s) and the copyright owner(s) are credited and that the original publication in this journal is cited, in accordance with accepted academic practice. No use, distribution or reproduction is permitted which does not comply with these terms. 